\title{
ZÁSADY FARMAKOTERAPIE V DETSKOM VEKU
}

\section{Oto Masár, Ján Murgaš}

Klinika anesteziológie a intenzívnej medicíny UKF a FN Nitra

Trnavská univerzita v Trnavě, Fakulta sociálnych vied a zdravotníctva

\section{ÚVOD}

Pri farmakoterapii pediatrických pacientov si treba uvedomit', že diet'a nie je zmenšenou kópiou dospelého. Existujúce dávkovacie schémy, odvodené od veku, hmotnosti, povrchu, môžu slúžit' len ako orientačné hodnoty, pretože neberú do úvahy individuálne rozdiely vo vývoji, ktoré sú značné najmä $\mathrm{v}$ najnižších vekových kategóriách. Podávanie liečiva $\mathrm{v}$ kritických obdobiach rastu môže ovplyvnit' d'al'ší vývin jedinca. Lieky, ktoré sú pre dospelého netoxické, môžu t’ažko poškodit' plod alebo diet'a najmä tým, že zasiahnu do vývojového programu štruktúr a funkcií.

Diet'a, predovšetkým v skorých vývojových štádiách, sa líši od dospelého organizmu vo vzt'ahu $\mathrm{k}$ lieku nielen $\mathrm{v}$ kvantitatívnych, ale aj kvalitatívnych parametroch. Zmenené podmienky na úrovni farmakokinetiky (nedostatočná kapacita biotransformačných enzýmov, eliminačných orgánov, znížená väzbová kapacita plazmatických bielkovín, zmenená distribúcia farmaka v organizme...), ale aj na úrovni farmakodynamiky (zmeny na úrovni receptorov i efektorov), nútia individuálne podl'a veku diet'at'a prehodnocovat' interakciu lieku s vyvíjajúcim sa organizmom.

Deti sa rastom a vývojom líšia nielen od dospelého, ale aj navzájom v jednotlivých vekových obdobiach (prenatálne obdobie, novorodenec, dojča, batol'a, diet'a predškolského a školského veku, puberta).

Príčinou problémov v rozhodovaní o použití liekov sú:

- farmakokinetické faktory

- farmakodynamické faktory

- compliance, aplikácia liekov

- rozdielne prejavy ochorení

- rozdielna reaktivita na noxu

\section{FARMAKOKINETICKÉ FAKTORY}

Farmakokinetika liečiv v detskom veku je ovplyvnená rozdielnymi faktormi v:

- resorpcii,

- distribúcii,

- eliminácii

liečiva v jednotlivých vývojových obdobiach.

\subsection{Novorodenecké obdobie}

Novorodenecké obdobie (prvých 28 dní života) je obdobím adaptácie organizmu zo stabilného vnútromaternicového prostredia na stále sa meniace vonkajšie prostredie. Novorodenec má funkčne nezrelé mnohé systémy organizmu, ktoré sú vystupňované u predčasne narodených detí.

Novorodenec je zvlášt' rizikovou vekovou skupinou pre výskyt nežiaducich účinkov liečiv pre vysoký stupeň expozície placentárnym transferom, materským mliekom a počas neonatálnej intenzívnej starostlivosti. Nie je dostatok farmakologických údajov u mnohých liečiv, používaných v neonatológii. Funkčný deficit v metabolizme a exkrécii liečiv môže u novorodenca spôsobit' prolongované pôsobenie liekov a tým jeho kumuláciu v organizme.

\subsubsection{Resorpcia}

Vstrebávanie liečiv u novorodencov sa riadi rovnakými princípami ako u väčších detí a dospelých. Okrem liekov, ktoré sa aplikujú priamo v mieste svojho pôsobenia (kožné a slizničné prípravky, inhalačné liečivá), sa liečivá dostávajú do organizmu enterálne alebo parenterálne a systémovou cirkuláciou prichádzajú $\mathrm{k}$ receptorom cielových tkanív.

Väčšina liečiv sa začína rezorbovat' u zrelého novorodenca po pôrode, ale prvých 1015 dní pretrváva relatívna achlorhydria ( $\uparrow$ rezorpcia PNC, $\downarrow$ fenobarbital), je prolongované vyprázdňovanie žalúdka a spomalená črevná peristaltika, znížená aktivita pankreatických enzýmov. $\mathrm{V}$ tomto veku nie je vhodné podávanie liečiv per os.

Vstrebávanie liečiva po intramuskulárnom alebo subkutánnom podaní závisí od krvného prietoku v mieste injekcie. Prekrvenie sa môže menit' pri kontrakcii svalov, poklese oxygenácie svalov, vazomotorickej instabilite, pri patologických stavoch (pokles minútového objemu srdca, respiračné poruchy), resorpcia je spomalená aj pri opuchoch. U predčasne narodených detí je parenterálne podávanie liečiv komplikované aj malou 
svalovou hmotou a slabým prekrvením, vstrebávanie liečiva zo svalu prebieha pomalšie ako predpokladáme. Liečivo sa môže kumulovat' v mieste podania a pôsobit' ako rezervoár. Ak sa náhle zlepší prekrvenie, v cirkulácii môžno zistit' až toxické koncentrácie rezorbovaného liečiva (pozor na srdečné glykozidy, antiepileptiká, aminoglykozidy).

U malých detí nemožno na aplikáciu intramuskulárnych liečiv používat' musculus gluteus maximus a skupiny deltoidného svalu, pre možnost' poškodenia nervového traktu $\mathrm{v}$ týchto areách.

U novorodencov a zvlášt' u nezrelých detí je zvýšená resorpcia lokálne podávaných liečiv cez kožu a sliznice. Tieto deti majú nedostatočne vyvinuté stratum corneum a teda aj zníženú ochrannú bariéru proti zložkám vonkajšieho prostredia. Perkutánna absorpcia je obrátená k pomeru hrúbky stratum corneum a hydratácii kože. Absorpcia medikamentov závisí aj od tukovej vrstvy, vaskularizácie, hydratácie a vývoja kožných žliaz. Pomer kožného povrchu k celkovej telesnej hmotnosti je u novorodencov trikrát väčší ako u dospelého človeka, preto pri lokálnej aplikácii dochádza $\mathrm{k}$ vysokej resorpcii liečiva (hyperkorticizmus po lokálnych kortikoidoch, methemoglobinémia po anilínových farbivách na označenie novorodencov, neurologické poruchy po hexachloroféne $\mathrm{v}$ prísade púdrov a detských mydiel).

\subsubsection{Distribúcia}

Rozdiely v zložení organizmu diet'at'a, v jeho vývoji a raste sa výrazne prejavujú aj v distribúcii podaných liečiv. Deti sa líšia rozdielnym zložením sérových bielkovín, objemom telovej vody, cirkuláciou, permeabilitou membrán, metabolizmom, čo sa prejavuje $\mathrm{v}$ distribúcii liečiv.

Faktory ovplyvňujúce farmakokinetiku liečiv:

- väzba na sérové bielkoviny,

- objem telovej vody a jej súčastí,

- metabolizmus liečiva $\mathrm{v}$ pečeni a iných orgánoch,

- stav celkovej a lokálnej cirkulácie,

- permeabilita telových membrán (endotelové bunky, hematoencefalická bariéra).

Väzba na bielkoviny. U novorodencov je znížená predovšetkým väzba na albumín. Aj koncentrácia sérových bielkovín, najmä albumínu, je v tomto vekovom období nižšia (klesá aj s gestačným vekom novorodenca a hypotrofiou plodu) a existujú pravdepodobne aj kvalitatívne rozdiely, ktoré znižujú väzbovú kapacitu bielkovín. Zo sérových bielkovín majú najväčší význam pre prenos liečiva albumín, lipoproteíny a orosomukoid. Albumín a ostatné sérové bielkoviny majú len obmedzený počet vol'ných väzbových miest, o ktoré kompetitívne sút'ažia liečivá s inými produktami metabolizmu. Znížená hladina a znížená väzobná schopnost' albumínu môže viest' u novorodencov (zvlášt' u nedonosených) $\mathrm{k}$ zvýšenej plazmatickej hladine vol'nej frakcie liečiva a tým $\mathrm{k}$ jeho toxicite (napr. ampicilin, diazepam, fenytoin, lokálne anestetiká...). Sulfonamidy vytláčajú bilirubín z väzby na albumín, čím vzniká nebezpečie vzniku jadrového ikteru u novorodencov.

Objem telovej vody. Telo diet'at'a obsahuje väčšie množstvo vody, najmä extracelulárnej tekutiny, čo sa významne odráža v distribúcii liečiva. Celková telesná voda tvorí novorodencov 70-80 $\%$ (u predčasne narodených detí až $85 \%$ ) hmotnosti. Množstvo telovej vody vekom postupne klesá, v dospelosti dosiahne 55-60 \% hmotnosti. Objem extracelulárnej tekutiny je u novorodencov a detí s nízkou pôrodnou hmotnost'ou podstatne väčší ako v neskoršom veku a tvorí až $50 \%$ telesnej hmotnosti. Znižuje sa len postupne a hodnoty objemu extracelulárnej tekutiny dospelých (20-25\%) dosahuje až v puberte. Najväčší pokles je v prvom roku života.

Diuréza u novorodencov začína $\mathrm{v}$ prvých 24 48 hodinách po pôrode, $v$ tomto období je znížená. Zníženie diurézy pretrváva dlhšie u predčasne narodených detí. Novorodenci aj deti do prvého roka života ovel'a rýchlejšie strácajú telovú vodu, sú ohrozené dehydratáciou. Odlišnosti v telových tekutinách ovplyvňujú liečbu v tejto vekovej kategórii. Liečivá, ktoré sú dobre rozpustné vo vode a málo sa viažu na bielkoviny, dosiahnu vo väčšom objeme extracelulárnej tekutiny nižšie koncentrácie ako u väčších detí a dospelých. Pri dehydratáciach, ktoré vznikajú u týchto detí vel'mi rýchlo, sa môže koncentrácia podávaného liečiva náhle zvýšit' pre znížený objem rozpúšt'adla a dosiahnut' aj toxické hodnoty.

Metabolizmus liečiva. Centrálnu úlohu v metabolizme liečiv má pečeň, ktorá ich metabolizuje oxidačnými a redukčnými procesmi, čím vznikajú aktívne alebo inaktívne pečeňové metabolity. Metabolizmus liečiv v pečeni prebieha jednak za účasti cytochrómu P450 (oxydo-redukčné reakcie), jednak konjugáciou (s kyselinou glukurónovou, sírovou a inými). U novorodencov (najmä u nedonosených) je znížená aktivita enzýmov cytochrómu P450, a to hlavne konjugačných enzýmov. Schopnost' metabolizovat' liek konjugáciou (na $\mathrm{kg}$ telesnej hmotnosti) sa u detí dosahuje až v 3. - 4. roku života (intoxikácia choramfenikolom - tzv. šedý syndróm u novorodencov bol 
dôsledkom neschopnosti pečene metabolizovat' chloramfenikol glukuronidáciou). Po prvom mesiaci začínajú enzýmy rýchlo vyzrievat'. Okrem kvantitatívnych zmien sú v novorodeneckom veku niektoré enzýmové systémy aj funkčne nezrelé, čo môže predlžovat' polčas liečiva (syntophylin) a môže dochádzat' k tvorbe iných metabolitov ako v neskoršom veku. Pretože novorodenec má zníženú schopnost' metabolizovat' liečivá, má mnoho liečiv podávaných det'om tejto vekovej kategórie nižší clearance a dlhší biologický polčas. Ak sa neupravia dávkovacie režimy liečiv, ktoré sa metabolizujú pečeňou, nezrelost' enzymatických systémov zvyšuje u novorodencov riziko výskytu nežiaducich účinkov. Niektoré liečivá, podávané matke pred pôrodom, môžu urýchlit' vyzrievanie fetálnych pečeňových enzýmov (napr. stimulující vliv phenobarbitalu), čím sa schopnost' novorodenca metabolizovat' liečivo zvyšuje. Preto terapeutický efekt liečiva aj jeho plazmatické hladiny budú nižšie ako sa očakávajú pri podaní v bežných dávkach pre novorodencov.

Stav celkovej a telesnej cirkulácie. Pre distribúciu a resorpciu liečiva je dôležitá aj celková a lokálna cirkulácia. Pri ochoreniach respiračného systému a pri poklese srdcového výdaja môže byt' narušená cirkulácia a znížená periférna perfúzia, ktoré ovplyvňujú farmakokinetiku liečiva.

Permeabilita telových membrán. Novorodenci aj dojčatá majú relatívnu nedostatočnost' hematoencefalickej bariéry. Do CNS tak prenikajú mnohé liečivá, ktoré sa tam v neskoršom veku nedostanú. Prenikaniu cez hematoencefalickú bariéru napomáha hypoxia, hypoglykémia, acidóza.

\subsubsection{Eliminácia}

Liečivá sa z organizmu vylučujú obličkami, pečeňou, plúcami a stolicou. Znížená vylučovacia schopnost' liečiv u novorodencov a detí s nízkou pôrodnou hmotnost'ou závisí od zníženej aktivity enzýmov metabolizujúcich liečivá v pečeni a od zníženej exkrečnej schopnosti obličiek. Mnohé látky (najmä antibiotiká) sa vylučujú v obličkách nielen glomerulárnou filtráciou, ale aj tubulárnou sekréciou, ktorá vyzrieva pomalšie ako funkcia glomerulov. Glomerulárna filtrácia u novorodencov je i v prepočte na telesný povrch významne nižšia než u detí starších, dozrieva až po 1. roku života. Glomerulárna filtrácia vo vzt’ahu $\mathrm{k}$ povrchu tela predstavuje u novorodenca len 30-40\% hodnôt dospelých, u detí narodených pred 34. gestačným týždňom je ešte nižšia. Postupne sa zvyšuje počas prvého týždňa, na 7. deň života je o $50 \%$ vyššia ako prvý deň života. Do konca prvého mesiaca života dosahuje 50-60\% hodnôt dospelých.
Liečivá, ktorých vylučovanie závisí hlavne od funkcie obličiek, sú $\mathrm{v}$ prvých týždňoch života vylučované vel'mi pomaly.

\subsection{Kojenecký a detský vek}

Vývoj a rast organizmu prebieha počas celého detského obdobia, čo spôsobuje rozdiely vo farmakokinetike lieku v detskom organizme. Čím je diet'a mladšie, tým je rast a vývoj intenzívnejší a v závislosti od toho je odlišná aj reakcia na liečivá. Terapeutické katastrofy sa nevyskytujú len v novorodeneckom období (poškodenie chrupu po tetracyklínoch, gray baby syndróm po užívaní chloramfenikolu-spôsobený redukciou aktivity glukuronyltransferázy a tým jeho kumuláciou v organizme, hemolytická anémia po podávaní vitamínu K...). Tkanivá detského organizmu odpovedajú na podané liečivo častokrát iným spôsobom ako tkanivá dospelého jedinca. Deti sa vyznačujú individuálnou variabilitou $\mathrm{v}$ citlivosti na liečivá. Niektoré deti potrebujú podstatne vyššie, iné naopak nižšie dávky lieku ako iné deti tej istej hmotnosti a rovnakého veku na dosiahnutie terapeutického účinku. Tieto rozdiely sa môžu prejavit' rezistenciou alebo naopak vysokou vnímavost'ou na podané liečivo.

U novorodencov a kojených detí treba počítat' aj s prechodom liečiv do materského mlieka. Dostávajú sa tam lieky, ktoré sú rozpustné v tukoch alebo majú charakter slabých zásad a lieky s nižšou molekulovou hmotnost'ou.

\subsubsection{Resorpcia}

U kojencov pretrváva spomalené vyprázdňovanie žalúdka a črevná peristaltika, hodnôt dospelých dosahuje okolo 6. mesiaca života. Žalúdočná kyselina dosahuje hodnôt dospelých až v 3. roku života. Pretrváva teda rýchla resorpcia penicilínu a jeho derivátov. Naopak viazne resorpcia liekov, ktoré potrebujú kyslé $\mathrm{pH} \quad \mathrm{v}$ žalúdku (fenobarbitalové deriváty). Aktivita pankreatických enzýmov dosahuje vyššie hodnoty až koncom prvého roka života, kolonizácia gastointestinálneho traktu sa ukončuje v 3. roku. Mnohé ochorenia ovplyvňujú resorpciu podaných liečiv. Hnačky znižujú vstrebávanie, malabsorpcie narušujú resorpciu liekov a vitamínov rozpustných v tukoch. U kojencov pretrváva zvýšená perkutánna absorpcia.

\subsubsection{Distribúcia}

Kojenci (aj nedonosené deti) majú oproti donoseným novorodencom menší podiel tukov $\mathrm{v}$ tele. $\mathrm{V}$ tkanivách, kde sa u väčších detí tvoria vysoké koncentrácie liposolubilných liečiv, sú u kojencov tieto liečivá len v malých množstvách. 
Väzba liečiv na sérové bielkoviny je znížená aj v detskom veku, znížená koncentrácia plazmatických bielkovín pretrváva až do puberty. Tá istá dávka liečiva sa môže prejavit' vyšším podielom vol'nej neviazanej frakcie a tým rýchlejším a silnejším účinkom alebo vedlajšími a toxickými účinkami. Znížená väzbová schopnost' sérových bielkovín sa môže výraznejšie prejavit' pri ochoreniach spojených s hypoproteinémiou a hypoalbuminémiou (ochorenia pečene, malabsorpcia, nefrotický syndróm, vrodené poruchy metabolizmu aminokyselín). Objem telovej vody na hodnoty dospelých klesá len pomaly. Dojčatá a malé deti rýchlo strácajú extracelulárnu tekutinu. Straty sú časté pri dyspepsii, hypertermii, dehydratácia vzniká vel’mi rýchlo.

\subsubsection{Metabolizmus}

Enzymatické systémy pečene dozrievajú postupne. Acetylácia, glukuronidácia a konjugácia dosahujú aktivitu dospelých v 6. mesiaci života, alkohokdehydrogenáza až v 5. roku života. Pečeň dojčat'a je relatívne vel'ká, tvorí asi $4 \%$ telesnej hmotnosti (dospelého len $2 \%$ ). Preto sa po dozretí enzymatických systémov pečene uplatní jej relatívne vel'ká hmotnost', ktorá patrí medzi dôležité faktory rýchlej eliminácie liečiva u batoliat a detí predškolského veku v porovnaní s dospelými. Pre distribúciu liečiva je rozhodujúci aj jeho pečeňový clearance, najmä extrakcia časti liečiva pri prvej cirkulácii cez pečeň po rezorpcii z gastrointestinálneho traktu. Niektoré lieky (analgetiká, betablokátory...) sa počas prvej cirkulácie pečeňou extrahujú vo vysokom stupni, ale ich extrakcia má prahový charakter. Po dosiahnutí tohto prahu sa koncentrácia liečiva $\mathrm{v}$ sére a v tkanivách prudko zvyšuje, čo môže spôsobit' nežiadúce účinky. Pečeňový prah sa líši v rôznych vekových obdobiach.

\subsubsection{Eliminácia}

Renálna eliminačná funkcia stúpa s vekom. Glomerulárna filtrácia a tubulárna sekrécia dosahujú hodnôt dospelých okolo 6. mesiaca života. (Eliminačný polčas teofylínu je: 30 hodín u predčasne narodeného diet'at'a, 14 hod. u novorodenca, 4,6 hodiny u 6-11 mesačného kojenca a 3,4 hodiny u 1-4 ročného diet'at'a.)

\subsection{Puberta}

Puberta je obdobie zrýchleného rastu, komplexom somatických, funkčných a psychických zmien a celkovou prestavbou organizmu, ktorá vedie $\mathrm{k}$ dospelému jedincovi, schopnému reprodukcie. V tomto období sú typické zmeny sekrécie mnohých žliaz s vnútorným vylučovaním. Nastávajú zmeny v zložení organizmu. Znižuje sa objem telovej vody, zvyšuje sekrécia pohlavných hormónov, zmnožuje sa tukové tkanivo. Vzostup sekrécie androgénov u chlapcov zvyšuje aktivitu oxidázového systému cytochrómu P 450 (urýchli sa vylučovanie teofylínových derivátov z organizmu).

\section{FARMAKOGENETICKÉ FAKTORY}

V metabolizme liečiv má úlohu aj genetický polymorfizmus, čo tiež ovplyvňuje farmakokinetiku liečiv.

\begin{tabular}{|c|c|c|}
\hline \multicolumn{3}{|c|}{ Priklady genetickeho polymortizmu v metabolizme lieciv: } \\
\hline defekt & liecivo & klinické dôsledky \\
\hline hydrolýza (pseudocholinesteráza) & sukcinylcholín & predížené apnoe u novorodencov \\
\hline oxidácia & bufuralol & exacerbácia beta-blokády, nauzea \\
\hline oxidácia & debrisoquin & ortostatická hypotenzia \\
\hline oxidácia & etanol & návaly krvi do tváre, kardiovaskul. symp- \\
\hline tómy & & \\
\hline oxidácia & mefenytoin & toxicita ataxia, sedácia \\
\hline oxidácia & spartein & $\begin{array}{l}\text { oxytocinové prejavy-ejekcia mlieka, } \\
\text { kontrakcie uteru }\end{array}$ \\
\hline oxidácia & tolbutamid & kardiotoxicita \\
\hline N-acetylácia & hydralazin & syndrom podobný lupus erythematosus \\
\hline N-acetylácia & izoniazid & periférna neuropatia \\
\hline hydroxylácia & warfarin & zvýšený antikoagulačný efekt \\
\hline
\end{tabular}


Farmakogenetické faktory sú zodpovedné napr. za zvýšenú citlivost' receptorov $\mathrm{k}$ liekom (útlm dychového centra morfínom), zníženie prahu pre vznik kŕčov po podávaní antihistaminík (s nutnou úpravou dávkovania u detî), hyperergné reakcie po sedatívach a hypnotikách (excitácia, kŕče) apod.

\section{SPÔSOBY PODANIA LIEKOV \\ A COMPLIANCE}

Skutočne užité dávky a tým aj efekt liečby závisí aj od liekovej formy vyrobeného liečiva a spôsobu jeho podania. Pre detských pacientov treba volit' čo najpraktickejšie liekové formy a čo najpohodlnejšie dávkovacie schémy. Existujú napr. určité doporučenia, od akého veku je možné diet'at'u možno podat' tablety, dražé, suspenziu.

$\mathrm{V}$ liečbe detských pacientov treba rešpektovat' osobitosti diet'at'a, jeho denný aj dávkovací režim. Pri vol'be liečebných schém mysliet' aj na možné liekové interakcie s potravou a vol'ne pre- dajnými liekmi. Výraz compliance ovšem znamená aj dobrú spoluprácu rodičov pri podávání liekov (dodržovanie dávok, intervalov podávania, príslušné kontroly $\mathrm{v}$ termínoch podl'a dohody s lekárom). U väčších školských detí a dorastu je často liečba celkom závislá na ich spolupráci. $\mathrm{V}$ pediatrii bohužial' nie je vzácna noncompliance, tj. nerešpektovanie hore uvedených pravidiel. Nie je napr. vzácne, že dorastenci prestanú užívat' imunosupresíva po transplantácii obličiek s následkom odhojenia štepu!

\section{ROZDIELNE PREJAVY OCHORENÍ A ROZDIELNA REAKTIVITA NA NO- $\mathrm{XU}$}

\subsection{Vplyv ochorení na farmakoterapiu detí}

$\mathrm{Na}$ farmakoterapiu pediatrických pacientov majú vplyv aj sprievodné ochorenia, ktoré menia farmakokinetiku liečiv.

\begin{tabular}{|c|c|c|}
\hline ochorenie & liečivo & efekt \\
\hline ikterus novorodencov & sulfonamidy & $\begin{array}{l}\text { jadrový ikterus vytesnením väzby bilirubinu na } \\
\text { albumín }\end{array}$ \\
\hline dysfunkcia obličiek & $\begin{array}{l}\text { aminoglykozidy } \\
\text { digoxin }\end{array}$ & $\begin{array}{l}\text { predížený polčas } \\
\text { predlížený polčas }\end{array}$ \\
\hline dysfunkcia pečene & teofylin & predížený polčas \\
\hline hypoalbuminémia & fenytoin & zvýšená vol'ná frakcia \\
\hline dehydratácia & aminoglykozidy & znížený distribučný objem \\
\hline edém, ascites & aminoglykozidy & zvýšený distribučný objem \\
\hline zlyhanie činnosti srdca & teofylin & znížený klírens \\
\hline & aminoglykozidy & zvýšený klírens \\
\hline vel’ké popáleniny & aminoglykozidy & zvýšený klírens \\
\hline cystická fibróza & & odlišná reakcia na liečbu ochorení \\
\hline imunodeficientné stavy & hormóny & zásah do endokrinného vývoja organizmu \\
\hline
\end{tabular}

\section{2. Interakcie liečiv}

Súčasné podávanie viacerých liečiv tomu istému diet'at'u môže modifikovat' účinky jednotlivých zložiek terapie. Interakacie sa môžu vyskytovat' na rôznych úrovniach účinku liečiva od jeho resorpcie až po efekt na úrovni receptorov. Výsledkom interakcie je často nepredvídatel'ný klinický účinok alebo nežiaduce až toxické účinky liečiva. Interakcie možu nastat' už v príprave na podávanie liečiva (zmiešanie viacerých liekov v injekčnej striekačke, infúznej flaši...). Liečivá navzájom ovplyvňujú svoju resorpciu z miesta podania (miesto vpichu, tráviaci systém, koža, inhalácia), väzbu na bielkoviny, afinitu $\mathrm{k}$ enzýmom pri svojom metabolizme, vylučovanie v obličkách, žlči, gastrointenstinálnom trakte, väz- bu na špecifické bunkové receptory. Farmakodynamické a farmakokinetické interakcie sa dajú predpokladat', ked' účinok jedného liečiva blokuje alebo potencuje účinok iného, súčasne podávaného medikamentu. Dnes existuje viacero tabuliek, ktoré upozorňujú na túto problematiku.

\subsection{Vedl'ajšie a nežiaduce účinky liečiv}

Každý medikamentózny zásah do organizmu je farmakoterapeutickým rizikom, ktoré sa prejavuje vznikom vedlajších alebo nežiaducich účinkov liečiv. Špecificita detského veku zvyšuje riziko vzniku nežiaducich vedlajších účinkov. V prospektívnej štúdii až $30 \%$ novorodencov malo nežiaduce účinky liečiv, z nich $25 \%$ predl- 
žovalo hospitalizáciu. Vedlajšś účinok znamená, že podávanie liekov má nejaké neobvyklé prejavy, ktoré ale organizmus nepoškodzujú (napr. po perorálnom podaní železa sa často objavuje tmavá stolica, redšie sú stolice po podaní mykofenolátu, po aplikaci očkovacej látky má diet'a bolestivost' v mieste vpichu a zvýšenú teplotu, po podaní niektorých liekov sa objavuje zmena farby moča či jeho výrazný zápach). Naproti tomu nežiaducim efektom je reakcia po podaní lieku, ktorá viac alebo menej môže viest' $k$ menším alebo väčším či dokonca závažným komplikáciám. Niektoré tieto nežiaduce reakcie môžu byt' vel'mi výrazné (severe adverse effects) alebo dokonca fatálne.

\subsection{Individuálne rozdiely $\mathrm{v}$ dávke liečiva}

$\mathrm{Aj}$ v prípade, že sa dávkovanie liečiva prispôsobuje veku, hmotnosti, povrchu tela a štádiu zrelosti, môže dôjst' k prekvapivej klinickej reakcii na liečivo. Liečivo nemusí dosiahnut' terapeutické koncentrácie v krvi a tkanivách, alebo naopak sa môžu objavit' nežiaduce komplikácie z vysokej koncentrácie liečiva alebo zo vzniku metabolitov, ktoré by sa v tejto vekovej kategórii nemali už objavit'. Príčinou môžu byt' farmakogenetické vplyvy, výživa, iné súčasne pôsobiace endogénne alebo exogénne vplyvy. Pri dávkovaní treba zvažovat' aj súčasné chronické ochorenia diet'at'a. $\mathrm{V}$ pediatrii by sa mala dodržiavat' zásada prispôsobovania dávky liečiva klinickej odpovedi diet'at'a a podl'a možnosti ju kvantifikovat' (diuréza po furosemide, pokles krvného tlaku po antihypertenzívach...). Dávkovanie liečiv odporúčané výrobcom nesmie byt' strnulou schémou, treba ho pružne prispôsobit' reakcii a celkovému stavu diet'at'a. Dnes už nie je problémom sledovanie plazmatických koncentrácií niektorých liečiv alebo ich metabolitov, u niektorých liekov sa dnes bez toho nedá zaobíst' (imunosupresíva po orgánových transplantáciách, antibiotiká na jednotkách intenzivnej starostlivosti, antiepileptiká pri záchvatovitých ochoreniach...).

\section{Dávkovanie liekov v pediatrii}

Aj napriek pokrokom vo farmakológii sa stále vyskytujú terapeutické chyby u detí. Liečivá, ktoré sú u dospelých netoxické, môžu t’ažko poškodit' plod alebo diet'a. Spektrum vedl'ajších a toxických účinkov je u detí odlišné a vyskytuje sa častejšie. Diet'a reaguje odlišne ako dospelý na mnohé lieky. Reakcia závisí od stupňa vývoja diet'at'a, jeho veku, výšky, hmotnosti, ochorenia. $\mathrm{S}$ ohl'adom na rozdiely vo farmakokinetike novorodencov a menších detí nie je vhodné redukovat' dávky liečiv podl'a veku alebo telesnej hmotnosti; tento prepočet je často neuváženým zjednodušením, ktoré môže spôsobit' nežiadúce účinky. Chýbajú často doporučené postupy (guidelines) pre detskú populáciu, preto sa stále vyskytujú chyby $\mathrm{v}$ dávkovaní, čo môže viest' $\mathrm{k}$ t’ažkým, občas až fatálnym komplikáciám u malých pacientov. Nie je prípustené ordinovat' det'om znížené dávky podl'a dávkovacích schém pre dospelých.

Dôležitý je i fakt, že farmaceutické firmy sa často vyhýbajú testovaniu liekov u detí v rámci klinických štúdií. Aj ked’ je logické, že liek bude účinný aj u detí, objaví sa v príbalovom letáku informácia „u detí sa nedoporučuje“. Napriek tomu pediatri takéto doporučenia často nerešpektujú a takéto lieky ordinujú, ale rodičom sa musí vysvetlit', prečo nie je rešpektované doporučenie firmy. V rámci EU je velká snaha donútit' firmy vykonávat' klinické testy i u dětí.

Po vstupe ČR a SR do EU se môžeme riadit' obecnými princípmi, doporučovanými pri farmakoterapii u detí. To najdôležitejšie, čo sa zmenilo, je veková hranica, od ktorej je možné podávat' lieky det'om ako dospelým, a to je teraz nie 15 let, ale 12 let!

V pediatrickej praxi sa najčastejšie používajú prepočty podla nasledujúcej schémy, ak presné dávkovanie pre jednotlivé vekové obdobia neuvádza výrobca:

dávka pre diet’a $=\frac{\text { dávka u dospelého } \mathrm{x} \text { povrch diet'at’a } \mathrm{v} \mathrm{m}^{2}}{\text { povrch dospelého } \mathrm{v}^{2}(1,73)}$

pričom sa povrch tela diet'at'a $\mathrm{v}^{2}$ určí pomocou nomogramov podl'a telesnej výšky a hmotnosti diet'at'a 


\begin{tabular}{cccc}
\hline $\begin{array}{c}\text { Telesná hmotnost' } \\
(\mathrm{kg})\end{array}$ & vek diet'at'a & povrch tela & $\begin{array}{c}\text { \% dávky pre dospe- } \\
\text { lého } \\
\left(\mathrm{m}^{2}\right)\end{array}$ \\
\hline 3 & novorodenec & 0,2 & 12 \\
6 & 3 mesiace & 0,3 & 18 \\
10 & 1 rok & 0,45 & 28 \\
20 & 5,5 roka & 0,8 & 48 \\
30 & 9 rokov & 1,0 & 60 \\
40 & 12 rokov & 1,3 & 78 \\
50 & 14 rokov & 1,5 & 90 \\
60 & 16-18 rokov & 1,7 & 102 \\
\hline
\end{tabular}

(Silver et al., 1983)

Skutočné dávky liečiva, ktoré sa dostávajú do organizmu, závisia od liekovej formy. Mnohé lieky sa pre deti pripravujú v tekutej forme. Suspenzie obsahujú nerozpustené čiastočky liečiva, ktoré treba pred každým použitím pretrepat'. Ak sa to zabúda, prvé dávky obsahujú menej liečiva ako posledné, plazmatické hladiny a tým aj terapeutický efekt sú na začiatku liečby nízke a neskôr v priebehu terapie sa môže vyskytnút' neočakávaný vedlajšśi účinok. Nerovnomerné rozptýlenie čiastočiek suspenzie je častou príčinou neúčinnosti alebo toxicity liečiva najmä u detí, ktoré užívajú fenytoín.

\section{ZÁVER}

Chyby v dávkovaní liečiv u detí sú spôsobené najčastejšie:

- odvodzovanie a zavádzanie dávok podla výskumov dospelej populácie

- nedostatok prístupných pediatrických liekových foriem

- nežiaduca koncentrácia medikamentov (malé dávky $\mathrm{v}$ mikrogramoch/kg hmotnosti napr. atropín, digoxin, prostaglandíny...)

- chyby v prepočítavaní dávok (častý prepočet miligramov na $\mathrm{kg}$ hmotnosti,

- hypertonické perorálne produkty a intravenózne roztoky (fenytoin, fenobarbital, digoxín...)

- limitácia príjmu tekutín (intravenózny erytromycín)

- neoznačené a nežiaduce ingrediencie (benzylalkohol)

- etické bariéry (klinický stav pacienta)

\section{LITERATÚRA}

Bakoš, E. 2004: Chirurgia, učebné texty FSV a ZUKF Nitra, $96 \mathrm{~s}$.

Berlin, C. M. jr 1997: Advances in pediatric phar- macology and toxicology. Pediatr, 44, s. 545-574

Ďurišová, A., Kriška, M. 2001: Farmakokinetika liečiv u novorodencov a malých detí. Čs. pediat., 56, s. 137-142

Ďurišová, A. 2002: Zásady farmakoterapie v detskom veku. In: Kriška, M. a kol. Memorix klinickej farmakológie. SAP, s. 145-154

Ďurišová, A., Kriška M. 2003: Lieky a laktácia. Čes.-slov. Pediat., 58, 10,s.649-652.

Ďurišová, A. 2003: Liekové interakcie u detí. In: Magulová, L., Božeková, L., Kriška, M. a kol.: Interakcie liečiv v klinickej praxi. SAP, Bratislava, s. $42-51$.

Ďurišová, A. 2004: Antimikrobiálna chemoterapia v neonatológii. Acta Chemother., 13, 2-3, s. 77- 80.

Ďurišová, A. 2004: Zlyhanie farmakoterapie v detskom veku. Čes.-slov. pediat., 59, 11, s. 589594.

Katzung, B. G. et al. 1994: Základní a klinická farmakologie. Nakladatelství a vydavatelství H\&H Jinočany, $1072 \mathrm{~s}$.

Kriška, M. a kol. 2002: Memorix klinickej farmakológie. SAP, 879 s.

Kriška, M., Ďurišová, A. 2003: Rizikové liečivá. In: Magulová L., Božeková L., Kriška, M. a kol: Interakcie liečiv v klinickej praxi. SAP, Bratislava, s. 37-41.

Loebstein, R., Koren, G. 1998: Clinical pharmacology and therapeutic drug monitoring in neonates and children. Pediat. rev, 19, s. 423-428.

Magulová, L., Trnovec, T. 2000: Farmakokinetické interakcie liečiv. Pharma Journal, 10, s. 130 $-32$.

Magulová, L., Kriška, M. 2002: Liekové interakcie. In: Kriška, M. a kol.: Memorix klinickej farmakológie. SAP, s. 169-179.

Niederhauser, V. P. 1997: Prescribing for children: Tissues in pediatric pharmacology. Nurse- 
Pract, 22, s. 16-26.

Reinhardt, D. (Hrsg.) 2004: Therapie der Krankheiten im Kindes-und Jugendalter, 7. Auflage, Springer,

Webové stránky venované uvedenej problematike:

http://www.bcpm.be/dosc/AC $\% 202005 \%$ 20Programme-05-01-15.18.draft.pdf http://www.actmagazine.com/ applied clinicaltrials / articleDetail.jsp? id=80205Príklady dávkovania liekov u detí x dospelých:

http:/ / www.tag-der-gesundheitsforschung.de/ dateien/tuebingen_osswald1.pdf 